International Journal of Applied Linguistics \& English Literature

ISSN 2200-3592 (Print), ISSN 2200-3452 (Online)

Vol. 1 No. 1; May 2012

\title{
Conjunctions in Malaysian Secondary School English Language Textbooks
}

\author{
Alicia Philip \\ College of Foundation and General Studies \\ Universiti Tenaga Nasional, Kampus Putrajaya \\ 43000 Kajang, Selangor Darul Ehsan \\ Mobile: 012-910 4335 Email: Alicia@ uniten.edu.my \\ Jayakaran Mukundan (Corresponding author) \\ Department of Language and Humanities Education \\ Faculty of Educational Studies \\ Universiti Putra Malaysia \\ 43400 UPM Serdang, Selangor, Malaysia
}

Mobile: 012- 2099717 Fax: 603-89435386

E-mails: jaya@educ.upm.edu.my; jayakaranmukundan@yahoo.com

\author{
Vahid Nimehchisalem \\ Department of Language and Humanities Education \\ Faculty of Educational Studies \\ Universiti Putra Malaysia
}

Mobile: 017-6678715 Emails: nimechie22@yahoo.com; vahid@educ.upm.edu.my

Received: 05-05- 2012

doi:10.7575/ijalel.v.1n.1p.1
Accepted: 20-05- 2012

Published: 31-05- 2012

URL: http://dx.doi.org/10.7575/ijalel.v.1n.1p.1

\begin{abstract}
The present research aims to investigate the distribution pattern of conjunctions and their ranking in two different corpora, namely the Malaysian school English language Textbook Corpus (Textbook Corpus) and the British National Corpus (BNC). An additional objective of the study was to find out how conjunctions had been presented in the Malaysian school English language textbooks (Forms 1-5). The method applied was qualitative content analysis. The findings indicated that coordinating conjunctions were the most frequent conjunctions that occurred in the five textbooks followed by subordinating and correlative conjunctions. The ranking of the different types of conjunctions in the Textbook Corpus was similar to that of the reference corpus, BNC. The results also indicated that the textbooks failed to present conjunctions effectively. The findings are expected to help textbook developers or language teachers in developing or adapting learning materials.
\end{abstract}

Keywords: Conjunctions, Textbook evaluation, Distribution patterns

\section{Introduction}

One of the important skills to be mastered in the acquisition of the English language is grammar. In order to be able to communicate effectively in English, one should be able to understand the grammar system of the language; without sufficient knowledge of the grammar system, one would fail to be a competent communicator of the language. Swan (1996) defined grammar as the rules that describe the combination, arrangement and change of words at sentence level that could produce different meanings. Grammar is governed by sets of rules that the speakers of the language use in order to get their meaning across (Ministry of Education, 1991).

Page $\mid 1$ 
International Journal of Applied Linguistics \& English Literature

ISSN 2200-3592 (Print), ISSN 2200-3452 (Online)

Vol. 1 No. 1; May 2012

The conjunction is an essential part of the English grammar system as it links phrases, clauses and sentences. It may also be used to indicate the relationship between ideas expressed in clauses and ideas expressed in the sentences. Bloor and Bloor (1995) describe the conjunction as a cohesive device that ties clauses or sections of a text to demonstrate meaningful patterns.

Conjunctions are classified into three different types, including coordinating, correlative and subordinating conjunctions (Good, 2002). This is the classification followed in the present study, but other classifications are also available in the literature. For instance, Celce-Murcia and Larsen-Freeman (1999) classify these grammar units into coordinating conjunctions, adverbial subordinators and conjunctive adverbials.

There are seven coordinating conjunctions, but, or, yet, for, and, nor and so (Celce-Murcia and Larsen-Freeman, 1999). The most common subordinate conjunctions are after, although, as, as if, as though, because, before, even if, even though, except, if now that, since, than, though, unless, until, when, where and while (Robin, 2008). Finally, the most commonly used correlative conjunctions are either... or, neither... nor, nor... but, not only... but also, and both... and (Good, 2002).

\subsection{Conjunctions in the Malaysian school syllabus}

Table 1 summarizes the conjunctions that are presented in the Malaysian syllabus:

Table 1. Conjunctions in the Malaysian secondary school English language syllabus (Curriculum specification MOE, 2003)

\begin{tabular}{|l|l|}
\hline Form & Conjunctions \\
\hline 1 & and ,but, or \\
\hline 2 & and, but ,or , so \\
\hline 3 & and ,but ,or, so \\
\hline 4 & either ...or, neither ...nor, although, however \\
\hline 5 & either ...or, neither ...nor, although, however \\
\hline
\end{tabular}

Based on Table 1, all three types of conjunctions are taught to the students over the period of five years of school. However, not all types of coordinating, subordinating and correlative conjunctions are taught to the students. Hughes and Heah (1994) state that students tend to misuse coordinating, subordinating and correlative conjunctions because they fail to understand the proper usage of these conjunctions in sentences as a result of lack of exposure to the different types of conjunctions.

The textbook is the main material used in the process of teaching and learning in the Malaysian schools that use the prescribed English language textbooks published by the Textbook Bureau of the Ministry of Education (Mukundan, 2009). These textbooks are guided by the syllabus that is set by the Ministry of Education in accordance to the national English language guideline. Research, however, indicates that the textbooks have been developed through intuition and assumptions (Mukundan, 2009; Mukundan \& Roslim, 2011). Since intuition was involved in their development, there are possibilities that the textbooks fail to present the new language elements efficiently.

There are a few studies carried out on the presentation of grammar items in the Malaysian textbooks. For example, Khojasteh (2010) investigated the presentation of modal auxiliary verbs. Roslim (2011) studied the presentation of prepositions in the Malaysian secondary school English textbooks. Leong (2011) also examined the presentation of articles in the Malaysian secondary school textbooks. However, there has been no research carried out on the presentation of conjunctions in the Malaysian English textbooks. Thus, there is need to research the presentation of conjunctions in these materials.

\subsection{Objectives of the study}

The purpose of this study is to investigate the presentation of conjunctions in Malaysian secondary school English language textbooks. The specific objectives of the study are:

1. To investigate the distributions of conjunctions used within and across the Malaysian secondary school English language textbooks (Form 1 to Form 5),

2. To compare the ranking of different types of conjunctions in the Textbook Corpus and the British National Corpus,

Page $\mid 2$ 


\section{International Journal of Applied Linguistics \& English Literature}

ISSN 2200-3592 (Print), ISSN 2200-3452 (Online)

Vol. 1 No. 1; May 2012

3. To analyze the presentation of conjunctions in the Malaysian secondary school English language textbooks (Form 1 to Form 5).

\subsection{Research questions}

The following research questions were formulated in order to meet the research objectives:

1. What are the distribution patterns of conjunctions used within and across the Malaysian Secondary School English Language textbooks (Form 1 to Form 5)?

2. Does the ranking of conjunctions have similar patterns in the Textbook Corpus and the British National Corpus (BNC)?

3. How have the conjunctions been presented in the Malaysian secondary school English language textbooks (Form 1 to Form 5)?

\section{Literature review}

\subsection{Textbook in ESL/EFL classroom}

Textbooks have been recognized as the central resources for teachers in assisting students to learn English in Malaysian schools (Nooreen \& Arshad, 2005). Textbooks function as a supplement to the teacher's instructions in ESL teaching and learning process. Thus, it seems true to regard them as the key component in language classes (Nooreen \& Arshad, 2005). O'Neil (1982) states that textbooks help provide the core framework for students to get in touch with the language and have a chance to look forward for the future lessons and get prepared for them.

On the contrary, textbooks are sometimes criticized for posing a potential problem to the education system and leading to educational failure (Swales, 1980 as cited in Sheldon, 1988). Sheldon (1988) views textbooks as being static and outdated because of the delays of writing and publications. The mismatch between the content of textbooks and the students' needs makes teachers unable to rely on them and obliges them to develop their own material in order to teach effectively. In Sheldon's (1988, p.239) words, textbooks are merely "tainted end product of an author or publisher's desire for quick profit."

Despite the researchers' contradictory arguments, textbooks still remain as important materials in the process of teaching and learning. Hence, language textbooks should be evaluated to ensure that a suitable selection or adaptation is made so that the material could match the students' needs and the aim of the teaching program.

\subsection{Corpus linguistics and English language teaching materials}

Corpora have been established as useful pedagogical aids in the language teaching and learning scene. Comprehensive volumes on the use of corpora in teaching and learning have been provided by a number of researchers such as Burnard and McEnery (2000), Connor and Upton (2004), as well as Sinclair (2004).

According to researchers (e.g., Biber \& Reppen, 2002; Carter \& McCarthy, 1995; Lawson, 2001), grammar descriptions are not appropriate in most textbooks. This may be attributed to several reasons. First, the descriptions in textbooks are often based on writer's intuition rather than empirical data. Additionally, textbooks often neglect register specific or discourse content specific information. They present grammatical and lexical patterns as equally generalizable. Moreover, some textbooks ignore the spoken language and are mostly based on the writers' norms. Finally, for pedagogical purposes, textbooks often simplify real language use.

Based on these attributes addressed, Lawson (2001) suggests that there are four areas of language in which corpus linguistics could help address the lack of fit highlighted by comparing textbook description and corpus findings. First, corpora could provide information on frequency of occurrence of linguistic features in natural languages. Second, they can also provide information on the variation of particular linguistic features across different contexts of use. Third, information on the salience of particular features could be provided through corpus based analysis. Finally, information on the discourse property of particular linguistic features could be provided through corpus linguistic analysis. Hence, it can be claimed that "corpus based analysis is an ideal tool to reevaluate the order of presentation of linguistic features in textbooks and to make principled decisions about what to prioritize in textbook presentation" (Barbieri \& Eckhardt, 2007, p. 322).

Regrettably, there is a wide gap between corpus based activities suggested by applied corpus linguists and the limited extent to which corpora are used in the ESL classroom (Mukherjee, 2004). Tribble (2000) agrees with this argument by claiming that there seems to be a clash between corpus linguists and teachers whereby corpus linguists are enthusiastic on the pedagogical use of corpora while teachers are reluctant to use corpora in their classrooms.

Page $\mid 3$ 


\section{एतA \\ International Journal of Applied Linguistics \& English Literature \\ ISSN 2200-3592 (Print), ISSN 2200-3452 (Online)}

Vol. 1 No. 1; May 2012

Although corpus data have been widely accepted as a relevant input for learners especially through dictionaries, the language of ELT textbooks is not consistent with corpus analysis findings (Mukherjee, 2006). The creation of such a consistency will result in more natural and real materials (Mukherjee, 2006).

According to Mcenery and Wilson (1996), the role of corpora goes beyond providing realistic examples of language usage in language pedagogy. A number of researchers have used corpus data to do critical studies on the existing language teaching materials. Most of these studies found out that there are considerable differences between the actual usage of language by native speakers and textbook language. Teaching materials often present inappropriate content. To avoid this, findings of corpus studies should be used in the production of ELT materials (Kennedy, 1998; Mindt, 1996). This can help the teacher highlight more common usage in the language classroom.

Conrad (2000) states that register variation is a vital feature of language. An aspect of register variation could be seen through linking adverbials where words and expressions connect two units of discourse. Although linking adverbials are seen as an important aspect for textual cohesion, they are insufficiently covered in most textbooks (Conrad, 2000). ELT textbooks can be further refined by taking corpus data into consideration.

\subsection{English language corpus in Malaysia}

There are not many English Language corpora that have been developed and used except for major ESL learners corpora such as the English Language of Malaysian school corpus (Arshad et al., 2002), Corpus or the Archive of Learner English Sabah -Sarawak (CALES) (Botley, De Alwis, Metom \& Izza, 2005).

Mukundan and Anelka (2007) compiled their pedagogic corpus which comprises the currently used Form 1 to Form 5 Malaysian English language textbooks. Mukundan and Roslim (2009) as well as Roslim and Mukundan (2011) used this corpus to provide information on the presentation of preposition in the textbooks. In addition, Mukundan and Khojasteh (2011) studied the presentation of modal auxiliary verbs using the same corpus.

On the other hand, Menon (2009) created textbook corpora including the Science and Technology (EST) textbooks and Science textbooks used in Malaysian secondary level schools. These corpora can be used to analyze and identify the lexical and grammatical patterns used in textbooks as well as vocabulary distribution patterns.

\subsection{Difficulties in learning conjunctions}

Learners may be unclear about what conjunctions really mean. This makes it difficult for students to appreciate them and use them accurately. It seems true to argue that students need to know the meaning of the conjunctions in order to master them (Steffani \& Nippold, 1997 cited in Lai, 2008). From a pedagogical perspective, the difficulties in learning conjunctions are mainly induced by inappropriate textbooks. According to Johns (1986), Field and Yip (1992) as well as Kaszubski (1998, cited in Lai, 2008), the most influential pedagogical source that results in ESL students' difficulties in learning conjunctions is the improper design of the textbooks. According to Lai (2010), most textbooks introduce conjunctions by providing the students with a list of conjunctions that are categorized according to their semantic functions. However, there are often no further explanations for the semantic function of each of the conjunctions. Zamel (1983) states that only providing the list of conjunctions and teaching students to just replace the conjunctions that come under the same semantic category would not guarantee the students' correct use of conjunctions in their daily writing or conversation as the list does not describe the logical relationship between ideas presented through the cohesive devices. In this respect, Lai (2010) contends that the manner in which the conjunctions are presented in most textbooks would direct students to conclude that words that come under the same functional categories are similar and interchangeable. This will leave the learner ignorant of the fact that even though some conjunctions share similar semantic functions, they may have different meanings.

Researchers warn that most textbooks provide practice and exercises that are too mechanical and insufficient (Lai, 2010). Zamel (1980) doubts whether mechanical practice on conjunctions (such as sentence combining exercises) in most English language textbooks could really improve students' written syntax. It is unrealistic for ESL teachers to expect such practice could improve students' written syntax and the overall quality of the students' writing (Zamel, 1980).

\section{Methodology}

Corpus based analysis is an ideal tool to evaluate the presentation of linguistic features in textbooks and to make principled decisions about what to prioritize (Barbieri \& Eckhardt, 2007). Through corpus based studies, the Page $\mid 4$ 
International Journal of Applied Linguistics \& English Literature

ISSN 2200-3592 (Print), ISSN 2200-3452 (Online)

Vol. 1 No. 1; May 2012

scope of certain features can be determined (Hulstijn, 1995). The present corpus based study used content analysis to analyze the frequency of conjunctions in the textbooks. According to Ary, Jacob and Sorensen (2010), content analysis is a method applied to identify specific characteristics of written or visual materials. Content analysis is widely used in educational research. Additionally, a qualitative analysis helped the researchers address the final research question.

\subsection{Material}

The material used in this study was the Malaysian school English language textbooks (Form 1 to Form 5) and their digitized corpus, referred to as the Textbook Corpus in the present paper. This corpus consists of 311214 running words. The reference corpus in this study was the British National Corpus (BNC), which is a very large corpus consisting of 100 million words from various written and spoken sources.

\subsection{Instrumentation}

Wordsmith tool designed by Scott $(1996,1997,1999)$ was used to analyze the data. The software is recognized as the most suitable tool for research of this nature (Mukundan, 2009; Mukundan \& Menon, 2006; Mukundan \& Roslim, 2009; Scott, 2001). Wordsmith tool provides word list frequencies. The location of words in the text can be identified using the concordance line.

\section{Results and discussion}

This section presents the findings of the present study.

\subsection{Distribution of conjunctions}

There are eight forms of conjunctions that are stipulated in the Malaysian secondary school syllabus. These forms are 'and', 'but', 'or', 'so', 'although', 'however', 'either...or', 'neither... nor'. In this study, in addition to these conjunctions, the researchers investigated the frequency of other conjunctions taught implicitly in the textbooks.

According to the Malaysian secondary school syllabus, in the first three years of secondary education, students are taught and exposed to coordinating conjunctions. Then, as they enter upper levels, they are exposed to subordinating and correlative conjunctions.

According to the results of the present study, collectively, there are 14055 conjunctions across the five Malaysian English language textbooks. The most frequent types of conjunctions are coordinating conjunctions with a frequency and percentage of 11059 and 78.68\%, followed by subordinating conjunctions (2930, 20.85\%). The least frequent conjunctions are correlative conjunctions $(66,0.47 \%)$.

Conrad (2000) stated that frequency information presented in a corpus based study will be able to help teachers to decide which item to emphasize and by providing more practice especially to low level students. Thornbury (2004) posits that the more frequently a grammar item is taught, the higher is the learner's chance to remember it. If a particular grammar structure is repeatedly presented to students, they will find it easier to gain mastery over the target structure (Celce-Murcia and Larsen-Freeman, 1983). Thus, based on the findings of this study, it can be recommended that students are in need of more exposure to correlative conjunctions and subordinating conjunctions because they have been under-presented in the textbooks. This suggests that teachers should give more emphasis to these conjunctions.

\subsection{Ranking of conjunctions in the two corpora}

Table 2 presents the ranking of conjuncations in the Textbook and reference corpora:

Table 2. Ranking of conjunctions in the Textbook corpus and BNC

\begin{tabular}{|c|c|c|}
\hline Ranking & $\begin{array}{l}\text { Textbook Corpus (Mukundan \& Anealka } \\
\text { Aziz, 2007) }\end{array}$ & $\begin{array}{l}\text { British National Corpus (BNC) (Kennedy, } \\
\text { 2002) }\end{array}$ \\
\hline 1 & Coordinating conjunctions & Coordinating conjunctions \\
\hline 2 & Subordinating conjunctions & Subordinating conjunctions \\
\hline 3 & Correlative conjunctions & (no data reported) \\
\hline
\end{tabular}

As the table shows, the ranking of conjunctions matches in the two corpora (Textbook Corpus and BNC). This finding indicates that the frequencies of the three types of conjunctions in the Textbook Corpus are in accordance

Page $\mid 5$ 


\section{International Journal of Applied Linguistics \& English Literature}

ISSN 2200-3592 (Print), ISSN 2200-3452 (Online)

Vol. 1 No. 1; May 2012

with the BNC. It is reported that in the BNC, there are 35622 conjunctions. Subordinating conjunctions have a frequency of 742. However, no records have been reported on the frequency of correlative conjunctions.

As the findings of the present study indicate, conjunctions are well represented in the Malaysian secondary school textbooks. Findings of this sort can be useful for teachers and students who can confidently use a textbook (McCarty, 2004).

\subsection{Presentation of conjunctions in the textbooks}

The third research question concerned the way in which conjunctions had been presented in the textbooks. The types of tasks that presented the conjunctions across the five textbooks were analyzed manually. Table 3 summarizes the results of this analysis.

Table 3. Types of tasks presented across Forms 1-5 English textbooks

\begin{tabular}{|c|l|}
\hline Forms & \multicolumn{1}{|c|}{ Types of tasks } \\
\hline 1 & Sentence combining (p.62, p.117 and p.122) \\
\hline 2 & $\begin{array}{l}\text { Fill in the blanks (p.35) } \\
\text { Matching (p.35) }\end{array}$ \\
\hline 3 & $\begin{array}{l}\text { Fill in the blanks (p.81 and p.86) } \\
\text { Sentence combining (p.208 and p.214) }\end{array}$ \\
\hline 4 & $\begin{array}{l}\text { Fill in the blanks } \\
\text { Sentence combining }\end{array}$ \\
\hline 5 & $\begin{array}{l}\text { Sentence combining (p.26) } \\
\text { Fill in the blanks (p.80) } \\
\text { Summary (p.27) }\end{array}$ \\
\hline
\end{tabular}

As the table shows, sentence combining, filling in the blanks, matching, and summary writing are the only task types providing practice on conjunctions for the students. Sentence combining task is the most common type of task while there is only one matching task in the Form 2 textbook and only one summary writing task in the Form 5 textbook. As it is evident from our results, these textbooks definitely lack variety in their task types. One of the reasons that a textbook might be a total turn-off to students is because it appears to be boring and unattractive. It has been suggested that lack of variety in the textbook may cause it to look dry and unattractive to the students. Hence, grammar practice should be presented and made more enjoyable and interesting to the students (Ur, 2006). This could be done by introducing interesting games which could reduce the tension and anxiety among students and add to their motivation. According to Tomlinson (1998), efficient ELT materials can achieve impact. This cannot be accomplished when exercises lack novelty and variety which will make them unattractive for the learner.

Additionally, in order to provide an answer for the third research question the frequencies of different types of tasks that addressed conjunctions in the five textbooks were analyzed. Table 4 presents the results of this analysis.

Table 4. Frequency of task types presenting conjunctions in Forms

1-5 English textbooks

\begin{tabular}{|c|c|c|}
\hline Types of tasks & Frequency & Percentages $(\%)$ \\
\hline Sentence combining & 7 & 50 \\
\hline Fill in the blanks & 5 & 35.71 \\
\hline Matching & 1 & 7.14 \\
\hline Summary & 1 & 7.14 \\
\hline Total & 14 & 100 \\
\hline
\end{tabular}

Page $\mid 6$ 


\section{International Journal of Applied Linguistics \& English Literature}

ISSN 2200-3592 (Print), ISSN 2200-3452 (Online)

\section{Vol. 1 No. 1; May 2012}

As the results indicate, overall there are 14 tasks related to conjunctions in the five English textbooks. Sentence combing task is the most common task with 50\% (7 tasks). This is followed by filling in the blanks, 35.71\% (5 tasks). Lastly, matching and summary writing tasks which occur once and constitute only $7.14 \%$ of the tasks throughout the five textbooks.

According to the related literature, sentence combining activities are the best activities that could reflect students' understanding of conjunctions (Zamel, 1983). Such activities could reinforce the conjunctions that have been taught to the students. However, sentence combining practice would be more effective when the semantic meaning of conjunctions is emphasized rather than directly providing students with the conjunction itself (Zamel, 1983).

On the other hand, fill in the blanks or gap-filling tasks were the second most frequent types of tasks that focused on conjunctions in the textbooks. It should, however, be noted that these types of activities may cause students to identify the use of conjunctions as lexical substitutions and to neglect the textual connections that are signified by conjunctions which may result in redundancy (Crewe, 1990). Thus, teachers need to be aware in using fill in the blanks activities by making sure that students are taught the appropriate usage of conjunctions so that they can realize the textual connections that are reflected through conjunctions in sentences.

Further analysis was carried out to find out whether conjunctions were presented explicitly or implicitly in the aforementioned tasks. The results of this qualitative analysis were tabulated. Table 5 summarizes these results.

Table 5. Explicit and implicit input on conjunctions across Forms 1-5 English textbooks

\begin{tabular}{|c|c|c|}
\hline \multirow[t]{2}{*}{ Forms } & \multicolumn{2}{|c|}{ Presentation of Conjunctions } \\
\hline & Explicit & Implicit \\
\hline 1 & $\begin{array}{l}\text { Focus on conjunctions: and, or, but } \\
\text { Presented in list form } \\
\text { Surface level information } \\
\text { Introduction of types of sentences }\end{array}$ & No implicit teaching of conjunctions \\
\hline 2 & $\begin{array}{l}\text { Very brief notes and examples of conjunctions: } \\
\text { and, but, so }\end{array}$ & $\begin{array}{l}\text { Introduction of compound sentences } \\
\text { Indirectly focusing on conjunctions: but, so }\end{array}$ \\
\hline 3 & $\begin{array}{l}\text { Introduced through a poster } \\
\text { Very brief explanation on the usage of } \\
\text { conjunctions in sentences } \\
\text { Presented in list form } \\
\text { Conjunctions introduced: and, or, but, so }\end{array}$ & $\begin{array}{l}\text { Introduction of compound sentences } \\
\text { coordinating conjunctions are highlighted } \\
\text { implicitly }\end{array}$ \\
\hline 4 & $\begin{array}{l}\text { Detailed explanations of subordinating } \\
\text { conjunctions with examples }\end{array}$ & $\begin{array}{l}\text { Introduction of compound and complex sentences } \\
\text { Indirect highlight on coordinating conjunctions: } \\
\text { and, or, but, so and subordinating conjunctions }\end{array}$ \\
\hline 5 & $\begin{array}{l}\text { Very brief notes and examples of correlative } \\
\text { conjunctions } \\
\text { Revision on conjunctions } \\
\text { Very brief notes and examples on the definitions } \\
\text { and usage of conjunctions } \\
\text { Very short notes on subordinating conjunctions }\end{array}$ & No implicit teaching of conjunctions \\
\hline
\end{tabular}

As it is evident from our findings, the textbooks fail to present conjunctions effectively. In most of the textbooks (excluding the Form 4 book), the grammar notes were too brief and superficial. In reference to Table 5, although the textbooks presented both explicit and implicit instruction of conjunctions, the explanations were too brief to help the students comprehend them. Most of the grammar notes or tasks merely provided lists of conjunctions with their semantic functions without further explanation on the semantic functions and syntactic restrictions in the use of each conjunction. As discussed above, it has been found that providing a list of a particular 


\section{एतA \\ International Journal of Applied Linguistics \& English Literature \\ ISSN 2200-3592 (Print), ISSN 2200-3452 (Online)}

Vol. 1 No. 1; May 2012

grammatical unit (like conjunctions) and directing the students to replace the items in the list that come under the same semantic category would not guarantee that they will be able to comprehend and use conjunctions in their writing task and in their daily conversations (Zamel, 1983).

It was also evident that conjunctions were often practiced through controlled exercises and drilling activities in all the textbooks. Very few were contextualized. Drilling activities do not always lead to students' mastery of the grammar item being taught. As Krashen (1981) warns, to acquire a language the learner does not really need extensive use of conscious grammatical rules in the form of tedious drills. Ellis (2002) states that grammar practices that are in a controlled situation do not give freedom to the students to learn the structures freely. According to Tomlinson (1998), most of what our students learn in controlled practice is only retained in short term memory. As he suggests, meaningful activities should be provided in textbooks that encourage outcome feedback and give a chance for the learners to check their language achievement. As the results of our analysis showed, the conjunction tasks in the textbooks mostly lacked such a quality. In this respect, Zamel (1983) suggested that instead of providing students with the choices of conjunctions in each of the sentences, students should be given the liberty to supply any conjunctions when practicing sentence combing tasks. Teachers then could discuss with the students on the appropriate conjunction that suits the blank. In this way, students might learn the correct usage of conjunctions and understand the necessity to choose the appropriate conjunctions to develop coherence and cohesive sentences.

Finally, all the five textbooks lacked communicative tasks on conjunctions. Nunan (1989) describes communicative tasks as tasks that could help students to comprehend, manipulate and interact with the target language. Cowen (2009, cited in Khojasteh, 2011) stated that communicative tasks require students to use the target structure frequently. Unfortunately, none of the tasks in any of the textbooks involved describing pictures, role playing, and writing letters that would support successful communication across different communication contexts.

\section{Conclusion}

The present study investigated the presentation of conjunctions in the Malaysian textbooks Forms 1 to Form 5 . The findings revealed that the frequency of conjunctions that are presented across Form 1 to Form 5 Malaysian English language textbooks increases as the students' level increases. It was also found that the distribution of coordinating conjunctions is higher as compared to subordinating and correlative conjunctions. Correlative conjunctions are the least occurring conjunctions among the three types of conjunctions. The findings, thus, suggest that more weight should be given to correlative conjunctions. Students are least exposed to correlative conjunctions as compared to coordinating and subordinating conjunctions. Hence, teacher intervention is needed. Teachers should come up with extra material that could help students learn more on correlative conjunctions to support the inadequacies of the English textbooks. The results also indicated that the Textbook Corpus is in accordance with the frequency ranking of conjunctions in the British National Corpus (BNC). Finally, the study looked at the types of tasks in which conjunctions were presented in the five English textbooks. These tasks lacked variety. There were only four types of tasks on conjunctions in the five books. Moreover, most of the tasks were controlled and emphasized drilling. Such task types, as it was discussed above, do not give freedom to the students to explore their understanding of grammar.

The findings of this study can help teachers to recognize the weakness and strength of the textbooks especially in teaching conjunctions. Curriculum planners could also benefit from this study by considering the distribution patterns of conjunctions within each textbook and making the necessary adaptations in order to meet the actual need of students. It is hoped that analyzing the presentation patterns of conjunctions in these textbooks will make textbook writers aware of the importance of such patterns in developing future textbooks. Cunningsworth (1995) and Ellis (1997) state that textbook evaluation could be a means of professional development for teachers. Mukundan (2007) argues that textbook evaluation should be considered as an important activity among language teachers.

Further research is required in the area. A large scale study that focuses on a larger sample could lead to more useful findings. Besides the Malaysian secondary school English language textbooks, analyzing the Malaysian primary school English language textbooks could reveal the distribution patterns of conjunctions in these textbooks as well. Comparing Malaysian secondary school English language textbooks with similar textbooks from another country such as Singapore could also lead to insightful findings. Finally, research could also look into collocation and colligation patterns of conjunctions to identify the word classes that often collocate and colligate with conjunctions.

Page $\mid 8$ 
International Journal of Applied Linguistics \& English Literature

ISSN 2200-3592 (Print), ISSN 2200-3452 (Online)

Vol. 1 No. 1; May 2012

\section{References}

Arshad A. S., Hassan. F., Mukundan. J., Kamarudin. G., Abd. Rahman. S. Z. S., Rashid. J., \& Vethamani. M. E. (2002). The English of Malaysian school students (EMAS) corpus. Serdang: UPM.

Ary, D., Jacobs, L. C. \& Sorensen, C. (2010). Introduction to Research in Education (8 ${ }^{\text {th }}$ ed.). California: Wadsworth Cengage Learning.

Barbieri, F., \& Eckhardt, S. (2007). Applying corpus-based findings to form-focused instruction: The case of reported speech. Language Teaching Research, 1(3), 319-346.

Biber, D. \& Reppen, R. (2002). What does frequency have to do with grammar teaching? Studies in Second Language Acquisition, 24, 199-208.

Bloor, T. \&Bloor, M. (1995). The Functional Analysis of English London, New York: Arnold

Botley, De Alwis, Metom \& Izza, (2005). CALES: a corpus based archive of learner English in Sarawak. A Report. Universiti Teknologi MARA.

Burnard, L. \& McEnery, T. (Eds.). (2000). Rethinking language pedagogy from a corpus perspective. Frankfurt: Peter Lang.

Carter, R. \& McCarthy, M. (1995). Grammar and the spoken language. Applied Linguistics 16(2), 141-58.

Celce-Murcia, Marianne and Diane Larsen-Freeman. 1983. The Grammar Book: An ESL/EFL Teacher's Course. New York: Newbury House.

Celce-Murcia, M. \& Larsen-Freeman, D. (1999). The Grammar book: an ESL/EFL teacher'scourse. $2^{\text {nd }}$ ed. Boston: Heinle\&Heinle.

Conrad, S. M. (2000). Will corpus linguistics revolutionize grammar teaching in the $21^{\text {st }}$ century? TESOL Quarterly 34(3), 548-60.

Connor, U and Upton, T. A. (Eds.). (2004). Applied corpus linguistics: A multi-dimensional perspective. Amsterdam: Rodopi.

Cowan, R. (2008). The Teacher's Grammar of English. Cambridge: Cambridge University. Cunningsworth, A. (1995). Choosing your coursebook. Oxford: Heinemann

Crewe, W.J. (1990). The illogical connectives. ELT Journal, 44(4), 316-325.

Ellis, R. (1997). Second language acquisition. Oxford: Oxford University Press.

Ellis, R. (2002). Grammar teaching - practice or consciousness raising? In J.C. Richards \& W.A. Renandya (Eds.), Methodology in language teaching: An anthology of current practice (pp. 167-174). Cambridge: Cambridge University Press.

Field, Y. \& Yip, L. (1992). A comparison of internal conjunctive cohesion in the English essay writing of Cantonese speakers and native speakers of English. RELC Journal,23(1), 15-28

Good, E.C. (2002). A grammar book for you and I-oops, me! : All the grammar you need to succeed in life. Virginia: Capital Books Inc.

Hughes, R. \& Heah, C. (1993). Common errors in English: Grammar exercises for Malaysians (2 ${ }^{\text {nd }}$ ed.). Shah Alam: FajarBakti.

Hulstijn, J.H. (1995). Not all grammar rules are equal: giving grammar instruction its proper place in foreign language teaching. In R. Schmidt (Ed.), Attention and awareness in foreign language learning (Technical Report No.6) (pp. 359-386). Honolulu: University of Hawaii, Second Language Teaching and Curriculum Center.

Johns, T. (1997), Contexts: the background, development and Mailing of a concordance-based CALL program. In Baker, P. Using Corpora in Discourse Analysis. London: Continuum.

Kaszubski, P. (1998). Enhancing a written textbook: national perspective. In S. Granger (Ed.), Learners English on computer. London: Longman.

Kennedy, G. (1998). An introduction to corpus linguistics. London: Longman Publishing.

Khojasteh, L. (2010). A corpus-based study of modal auxiliary verbs used in the Malaysian English language textbooks. (Unpublished doctoral thesis). Serdang: Universiti Putra Malaysia. 


\section{International Journal of Applied Linguistics \& English Literature}

ISSN 2200-3592 (Print), ISSN 2200-3452 (Online)

\section{Vol. 1 No. 1; May 2012}

Khojasteh, L. (2011). Modal auxiliary verb in prescribed Malaysian English textbooks. English Language Teaching 4(1), pp.79-89.

Krashen, S. (1981). Principle and Practice in second language acquisition English language: Teaching series. London: Prentice Hall.

Lai, Y.Y. (2008). A corpus investigation of conjunctive use in the Taiwanese students' writing. (Unpublished master thesis). Ming Chuan University, Taiwan.

Leong, A. (2011). Analysis on the use of articles in the Malaysian secondary school English language textbook. (Unpublished master thesis). Serdang: University Putra Malaysia.

Lawson, A. (2001). Rethinking French grammar for pedagogy: The contribution of French corpora. In Simpson, R.C. \& Swales, J.M., (Eds.), Corpus linguistics in North America: Selections from the 1999 Symposium (pp. 179-194). Ann Arbor, MI: The University of Michigan Press.

McCarty, M. (2004). From Corpus to coursebook. Cambridge: Cambridge University Press.

McEnery, T. \& Wilson, A. (2001). Corpus linguistics: An introduction ( $2^{\text {nd }}$ ed.). Edinburgh: Edinburgh University.

Mellon, J.C. (1969). Transformational sentence-combining: A method for enhancing the development of syntactic fluency in English composition. Urbana, Illinois: NCTE.

Menon, S. (2009). Corpus-based analysis of lexical patterns in Malaysian secondary school science and English for science and technology textbooks (Unpublished doctoral thesis). Serdang: Universiti Putra Malaysia.

Mindt, D. (1996). English corpus linguistics and the foreign language teaching syllabus in J. Thomas and M. Short (eds.). Using corpora for language research (pp. 232-247). Harlow: Longman.

Ministry of Education, Malaysia (1991). Compendium: A handbook for ELT teachers. vol 2. Kuala Lumpur: Maziza.

Mukundan, J. (2007). Evaluation of Language Textbooks: Some Important Issues for consideration. Journal of NELTA, 12(1\&2).

Mukundan, J. (2009). ESL textbook evaluation: A composite framework. Köln, Germany: Lambert Academic Publishing.

Mukundan, J. \& Anealka, A. H. (2007). A forensic study of vocabulary load and distribution in five Malaysian Secondary School Textbooks (Forms 1-5). Pertanika Journal of Social Science and Humanities, 15(2), 59-74.

Mukundan, J. \& Khojasteh, L. (2011). Modal auxiliary verbs in prescribed Malaysian English textbooks. English Language Teaching, 4(1), 79-89.

Mukundan, J. \& Roslim, N. (2009). Textbook representation of prepositions. English Language Teaching, 2(4), $123-130$.

Mukherjee, J. \& Rohrbach, J. (2006). Rethinking applied corpus linguistics from a language-pedagogical perspective: New departures in learner corpus research in B. Kettemann \& G. Marko (eds.). Planning and gluing corpora: Inside the applied corpus linguist's workshop. Frankfurt: Peter Lang.

Nooreen, N. \& Arshad A. S. (2005). Examining the Importance of EST and ESL Textbooks and Materials: Objectives, Content and Form. English for Specific Purposes World. Retrieved from http://www.esp-world.info/Articles_9/textbooks.htm

Nunan, D. (1989). Designing tasks for the communicative classroom. Cambridge: Cambridge University Press.

O’Neill, R. (1982). Why Use Textbooks? ELT Journal. 36(2), 23-30.

Robin, T.G. (2008). Intermediate English Grammar for ESL learners. United States of America, USA: McGraw Hill.

Sinclair, J. (2004). Intuition and annotation - the discussion continues. In Advances in corpus linguistics. Papers from the 23rd International Conference on English Language Research on Computerized corproa (ICAME 23). Göteborg 22-26 May 2002., eds. Karin Aijmer and Bengt Altenberg, 39-59. Amsterdam/New York: Rodopi.

Sheldon, L. (1988). Evaluating ELT textbooks and materials. ELT Journals, 42(4). 


\section{International Journal of Applied Linguistics \& English Literature}

ISSN 2200-3592 (Print), ISSN 2200-3452 (Online)

Vol. 1 No. 1; May 2012

Smith, C., Butler, N.L., Griffith, K.G., \&Kritsonis, W.A. (2007). The Role of Communication Context, Corpus-Based Grammar, and Scaffolded Interaction in ESL/EFL Instruction. The Lamar University Electronic Journal of Student Research, 4.

Scott, M. (1996, 1997, 1999). Versions (1.0, 2.0, 3.0, 4.0) WordSmith Tools. Oxford: Oxford University Press.

Steffani, S.A. \& Nippold, M.A. (1997). Japanese speakers of American English: Competence with connectives in written language. Journal of Speech, Language and Hearing Research, 40, 1048-1055.

Swan, M. (1996). Practical English usage. Oxford: Oxford University Press.

Thornbury, S. (2004). How to teach grammar? Malaysia: Pearson Education Limited.

Tribble, C. (2000): Practical uses for language corpora in ELT, In P. Brett \& G. Motteram (eds.). A special interest in computers: Learning and teaching with information and communications technologies (pp. 31-41), IATEFL, Whitstable: Kent.

Ur, P. (2006). Grammar practice activities. Cambridge: Cambridge University Press.

Zamel, V. (1980). Re-evaluating Sentences combining Practice. TESOL Quarterly 14(1), 81-90.

Zamel, V. (1983). Teaching those missing links in writing. ELT Journal, 37(1), 22-29. 